\title{
A review of the CITES listing of big-leaf mahogany
}

Arthur G. Blundell

\begin{abstract}
Big-leaf mahogany Swietenia macrophylla King (Meliaceae) is the premier timber species of Latin America. A lack of law enforcement allows widespread illegal logging, and its unsustainable harvest depletes local stocks, necessitating a shift in sources of supply. To better control this exploitation, parties to the Convention on International Trade in Endangered Species of Wild Fauna and Flora (CITES) recently elected to list mahogany on Appendix II. This listing requires exporting countries to verify that each shipment was legally acquired and its harvest was non-detrimental to the survival of mahogany. The CITES listing poses
\end{abstract}

considerable challenges: 1) there is no precedent, as mahogany is the first commonly traded timber species listed on Appendix II, and 2) given current, unsustainable logging practices, CITES regulations will be difficult to implement. This paper synthesizes information on the conservation and management of mahogany that informed the listing decision, and provides recommendations for implementation, including timber tracking to ensure legality.

Keywords Chain-of-custody, CITES Appendix II, illegal logging, Latin America, mahogany, Swietenia macrophylla, tropical dry forest.

\section{Introduction}

For the first time, a commonly traded timber species is to be regulated under Appendix II of CITES (the Convention on International Trade in Endangered Species of Wild Fauna and Flora). At the 12th Conference of the Parties, held in Chile in November 2002, countries voted 68-30 to uplist big-leaf mahogany Swietenia macrophylla King (Meliaceae), the premier timber species of Latin America, from Appendix III to Appendix II. This means that, from November 2003, exporting countries must verify that each shipment was legally acquired and that its harvest was not detrimental to mahogany's role in its ecosystem. Implementation will test whether CITES can manage trade to protect, not just Latin America's most valuable timber resource, but the trade itself. In this paper, I review the justification for the Appendix II listing, in particular the evidence of widespread illegal, unsustainable logging, and examine issues regarding implementation.

\section{CITES Appendix listing criteria}

The criteria for CITES Appendix II focus on sustainability. In the proposal (CITES, 2002), the proponent countries, Guatemala and Nicaragua, argued that

Arthur G. Blundell National Center for Environmental Assessment, Office of Research and Development, US Environmental Protection Agency, 3426 16th ST NW \#308, Washington, DC 20010, USA.

E-mail art.blundell@alum.dartmouth.org

Received 10 July 2002. Revision requested 15 April 2003. Accepted 28 October 2003 mahogany meets the criteria for Appendix II. In particular, 'the harvesting of specimens from the wild for international trade has, or may have, a detrimental impact on the species by ... exceeding, over an extended period, the level that can be continued in perpetuity' (criterion from CITES Resolution Conference 9.24, Annex 2 a). There is widespread agreement among the international community that mahogany qualifies for such listing (Table 1). The CITES proposal provided two lines of evidence to justify the mahogany listing: biology and trade.

\section{Biological parameters}

Mahogany is an emergent canopy tree (c. $35 \mathrm{~m}$ tall) that has a clumped distribution in seasonally dry forests (mean annual temperature $>24^{\circ} \mathrm{C}, 1,000-2,000 \mathrm{~mm}$ rain per year) from Mexico $\left(23^{\circ} \mathrm{N}\right)$ to the southern Amazon (185; Lamb, 1966; Table 2). This habitat faces severe pressure, as it is highly valued for agriculture and livestock grazing. Forests have been cleared from more than $63 \%$ of mahogany's range in Meso-America and $26 \%$ in South America (Table 2). Logging roads facilitate this deforestation (Verissimo et al., 1995). Generally, the only timber species sufficiently valuable to justify building logging roads is mahogany (Howard et al., 1996). Logging of mahogany is strongly correlated with forest fires (Nepstad et al., 1999, Cochrane, 2001), because removal of trees generates flammable debris and opens the canopy, drying out the understorey, and thus fires become more likely, and burn longer and hotter. 
Table 1 Classification of the conservation status of big-leaf mahogany by international organizations (from CITES, 2002).

\begin{tabular}{ll}
\hline Organization & Comment \\
\hline CITES (PC11 Doc.13.3) & Qualifies for CITES Appendix II (meets criterion II Bi) \\
UNEP-World Conservation Monitoring Centre & Qualifies for CITES Appendix II (meets criterion II Bi) \\
IUCN (2002 Red List) & Vulnerable (based on criteria A1cd+2cd) ${ }^{1}$ \\
International Board for Plant Genetics Resources & High-priority for genetic conservation \\
International Tropical Timber Organization & High-priority species \\
Food and Agriculture Organization Panel of Experts on Forest Gene Resources & High-priority for in situ conservation \\
Asociación Nacional para la Conservación de la Naturaleza (Panamá) & Threatened \\
IBAMA (Brazil) (Proc. No. 006/92 N) & In danger of extinction \\
Brazilian Botanical Society & In danger of extinction \\
US National Research Council & Vulnerable \\
Convention on Nature Protection and Wildlife Preservation in the & Nicaragua listed on Annex (23/04/41) \\
Western Hemisphere & Venezuela listed on Annex (3/02/42) \\
& Brazil listed on Annex (22/10/65) \\
& Costa Rica listed on Annex (22/10/65) \\
\hline
\end{tabular}

${ }^{1}$ Experiencing population decline of $>50 \%$ over three generations due to habitat loss and overexploitation.

Table 2 Habitat and trade of big-leaf mahogany. Area of forest, habitat loss, and percent of area protected within the range of mahogany. Forest area and loss are based on Landsat images from the mid 1990s (data are from CCT, 2000, and CI, 2001). Export data are for 1999 and are based on CITES data (TRAFFIC, 2001). Illegal trade is based on country reports to the CITES Mahogany Working Group (Government of Belize, 2001; Government of Bolivia, 2001; Government of Costa Rica, 2001; Government of Perú, 2001).

\begin{tabular}{|c|c|c|c|c|c|c|}
\hline \multirow[b]{2}{*}{ Country } & \multicolumn{3}{|c|}{ Mahogany's range } & \multicolumn{3}{|l|}{ Trade } \\
\hline & $\begin{array}{l}\text { Area of forest } \\
\text { (million ha) }\end{array}$ & Habitat loss (\%) & Area protected (\%) & $\begin{array}{l}\text { Exports } \\
\left(\mathrm{m}^{3} \text { year }^{-1}\right)\end{array}$ & $\%$ total & $\begin{array}{l}\text { Illegal trade } \\
\text { (\% of harvest) }\end{array}$ \\
\hline Brazil & 139.6 & 27 & 2 & 59,758 & 52.9 & $>80$ \\
\hline Perú & 56.5 & 5 & 4 & 35,170 & 31.1 & $30-40$ \\
\hline Bolivia & 18.9 & 33 & 11 & 8,520 & 7.5 & \\
\hline Nicaragua & 5.0 & 47 & 1 & 5,165 & 4.6 & \\
\hline México & 3.6 & 76 & 4 & 212 & 0.2 & \\
\hline Ecuador & 3.5 & 5 & 27 & 77 & 0.1 & \\
\hline Colombia & 2.6 & 77 & 1 & 0 & 0.0 & \\
\hline Guatemala & 2.8 & 47 & 11 & 406 & 0.4 & \\
\hline Honduras & 1.7 & 55 & 4 & 1,324 & 1.2 & \\
\hline Venezuela & 1.2 & 91 & 1 & 0 & 0.0 & \\
\hline Panamá & 1.0 & 75 & 7 & 23 & 0.0 & \\
\hline Belize & 1.0 & 32 & 10 & 2,326 & 2.1 & 40 \\
\hline Costa Rica & 0.3 & 84 & 2 & 0 & 0.0 & 60 \\
\hline El Salvador & 0.1 & 80 & 0 & 0 & 0.0 & \\
\hline
\end{tabular}

Even where forest remains, a vast amount has been selectively logged for mahogany (Verissimo \& Grogan, 1998); c. $85-90 \%$ of adults are commonly removed (Verissimo et al., 1995; Gullison et al., 1996; Barreto et al., 1998; Zimmerman et al., 2001; Grogan, 2001). For example, although still mostly forested, mahogany has been decimated in Santa Cruz and Beni, Bolivia (UNEP-WCMC, 1999). Mahogany used to be abundant in Colombia, especially in the departments of Santander del Norte and del Sur, César, Magdalena, and Chocó, but is now considered commercially extinct and trade is banned (Government of Colombia, 2001). In Brazil, mahogany is commercially extinct in most of Tocantins, south-east Pará, Mato Grosso, and Rondônia (Grogan,
2001). Mahogany was once abundant in Belize, but commercial-sized trees are rare (Weaver \& Sabido, 1997). Thus, deforestation rates underestimate the loss of mahogany from Latin American forests.

The harvest of mahogany generally exceeds the capacity for regeneration (Gullison et al., 1996; Snook, 1996; Grogan et al., 2002). Reproduction is compromised by the removal of adult seed trees, especially the largest and most fecund individuals. For example, Gullison et al. (1996) calculated that in Bolivia post-harvest seed production is only $10 \%$ of mahogany seed input before logging, and Grogan (2001) found similar results in Brazil. Logging further increases inbreeding; in Bolivia, outcrossing rates declined by $15 \%$ in a stand when the 
surrounding forest was logged (Loveless \& Gullison, 1996). In Central America, logging was associated with reduced genetic diversity of regenerating mahogany (Gillies et al., 1999). Furthermore, the small gaps in the canopy caused by selective logging do not favour growth and survival of light-demanding mahogany seedlings (Gullison, 1995; Snook, 1996; Grogan et al., 2002). For example, in Brazil, although $65 \%$ of $2-3$ year-old logging gaps contained regenerating mahogany, only 2 seedlings in 40 gaps were growing vigorously (Grogan et al., 2003). In Bolivia, Gullison et al. (1996) searched 39 logging gaps $>20$ years old and found only three mahogany saplings.

Clearly new patterns of exploitation are necessary if mahogany is to be managed sustainably (Grogan et al., 2002). It will be a major challenge to develop logging regimes that favour the growth of light-demanding species, such as mahogany, in selective-logging conditions where little of the canopy is opened. Long-term solutions may include enrichment planting in logging gaps and inter-cropping using mahogany within agrosystems (Grogan et al., 2002).

\section{Trade parameters}

Exploitation is mainly driven by mahogany's high export value and international demand $\left(\$ 1,700 \mathrm{~m}^{-3}\right.$; ITTO, 2003). Depending on the country, the majority of the best grades are exported, with the poorer quality wood retained for domestic use (Robbins, 2000). Logging operations are usually pre-financed by international buyers, generally from the US (e.g. US financial backing of logging in Perú; SPDA, 2002). Without this capital, much logging could not occur.

Where logging occurs, it follows a pattern of local depletion and shifting supply. Until the early 1970s Central America dominated the world's mahogany market, but now the region supplies less than $10 \%$ of international trade (Robbins, 2000). Brazil has experienced several shifts in supply. By the early 1970s mahogany had been depleted along the Araguaia River and its tributaries in south-east Pará, and trade was opened up to the west by the new state highway PA-150. When this area was exhausted, by the early 1980s, extraction shifted further west to the unpaved PA-279, towards the Xingu River (Grogan et al., 2002). Meanwhile, commercial stocks were essentially eliminated from the state of Rondônia between 1980-1985 (Browder, 1987). During the 1980s-1990s the wave of extraction moved west across northern Mato Grosso and southern Pará (Grogan et al., 2002). As Brazilian trade fell due to depletion of the richest areas, Bolivia became the world's leading exporter by 1996 . However, it too was quickly depleted and it now supplies only c. $8 \%$ of international trade (Robbins, 2000). By contrast, exports from Perú have risen by c. 300\% since 1996 (Blundell \& Rodan, 2003). Even during periods of severe depletion the appearance of sustainable production (i.e. constant production volumes) may be maintained through sequential reductions in diameter limits (Weaver \& Sabido, 1997).

Although it is clear that mahogany is being depleted across its range, reliable estimates of trade are difficult to obtain. For example, the official reports of legal imports to the US, the world's largest importer (CITES, 2002), vary dramatically. For the period 1997-1999, US import volumes reported by CITES exporting countries, the US CITES Authority, and US Customs differed by $17-91 \%$ (Blundell \& Rodan, 2003). The extent of the illegal trade is even more difficult to ascertain. Mahogany can be easily smuggled because customs agents have difficulties making species' identification of sawn timber. For example, a review by Canada Customs found that c. $60 \%$ of mahogany shipments were incorrectly labelled as generic tropical wood instead of mahogany (Gerson, 2000). The actual trade in mahogany is probably much larger than the reported legal trade.

Range countries estimate that illegal logging comprises $30-80 \%$ of all mahogany harvested (Table 2), and illegal logging has been estimated to be 1-2 times the size of legal harvest in Central America (CCT, 2000). Over the past decade in Bolivia 'mahogany populations were in a rapid and drastic decline as a consequence of illegal cutting' (Government of Bolivia, 2001). The Chimanes project in Beni, sponsored by the International Tropical Timber Organization to demonstrate sustainable management, was unable to control illegal logging. The three logging companies violated management plans and rapidly depleted the standing mahogany. The companies then resorted to buying illegal mahogany harvested from indigenous territories (Gullison, 1995).

In Peru, currently the world's largest exporter, officials estimate that $30-40 \%$ of mahogany trade is illegal (TRAFFIC, 2001). In 1999 a state of emergency was declared within the Amazonian departments of Madre de Dios and Tahuamanu, and senior officials were fired because of their implication in rampant illegal logging (Ministerial Resolution 951-99-AG). A US-financed sawmill was charged with illegal logging (Supreme Decree 047-99-A), including building c. $100 \mathrm{~km}$ of illegal logging roads. The joint venture between Newman Lumber of Mississippi, USA, and IMT of Perú processed c. 59,000 $\mathrm{m}^{3}$ of sawn mahogany between 1998 and 1999, worth c. \$44 million (SPDA, 2002), 10\% more than the entire volume of exports that the Peruvian CITES Management Authority reported during the same period (c. 55,000 $\left.\mathrm{m}^{3}\right)$.

In Brazil, indigenous lands represent a major source of mahogany, although the 1988 Constitution prevents commercial logging in these territories. Over 2 million $\mathrm{m}^{3}$ were extracted from native lands between 1982 and 1992, 
almost exclusively by non-indigenous loggers (Hering \& Tanner, 1998, based on data from FUNATURA, 1993). In 1992 the Secretary of the Environment, Jose Lutzenburger, wrote an open letter pleading with the international community not to buy mahogany as most was illegally extracted from indigenous areas, sometimes at the cost of the lives of Amerindians (Blundell \& Gullison, 2003). At that time, Friends of the Earth-UK launched a campaign (Mahogany is Murder) against mahogany due to the connection between logging and the death of indigenous peoples (Hering \& Tanner, 1998). Accusations were made that loggers had murdered to get access to mahogany. This lead to a boycott in the UK, and trade fell by $>95 \%$. But the trade merely moved to the US and illegal logging continued, with or without local agreement; companies often coerced sales at low prices as an alternative to outright theft (as little as $\$ 30$ per tree) (Zimmerman et al., 2001). As the Government of Brazil (2001) has stated 'Given the extraordinary value of mahogany, it is extremely difficult to protect it . . f from illicit cutting.'

Only 3\% of mahogany's range lies within protected areas (Table 2), but even these areas provide little protection from illegal, unsustainable logging, and the reserve network is insufficient to protect mahogany throughout its range (Gullison et al., 2000). Although some remote parks protect individual mahogany populations most, such as the Pacaya-Samiria National Reserve in Perú, are a source of illegally harvested timber (Government of Peru, 2001). In summary, the CITES (2002) proposal argued that mahogany met the criteria for Appendix II because illegal and unsustainable exploitation across its range threatens prospects for future harvests.

\section{Actions prior to Appendix II listing}

Before the CITES parties elected to list mahogany on Appendix II, individual countries pursued a variety of policies to better manage the resource. Among these policies, countries passed legislation requiring sustainable management, and they voluntarily listed mahogany on CITES Appendix III.

\section{CITES Appendix III}

Unlike Appendix I or II, which require CITES parties to vote on a listing, an Appendix III listing is a voluntary act that a country takes to protect its species. Under Appendix I and II, all countries must provide shipments with export permits. However, under Appendix III, only the listing country must provide export permits to verify that each shipment was legally obtained. All the other countries in the range are only required to provide shipments with a certificate of origin, a document that identifies the country where the shipment was harvested. In 1995, after two failed attempts (in 1992 and 1994) to list mahogany on Appendix II, Costa Rica unilaterally listed its population on Appendix III. After a third listing proposal in 1997, other range countries added their populations to Appendix III: Bolivia (March 1998), México (April 1998), Brazil (July 1998), Perú (June 2001) and Colombia (October 2001). Despite the CITES regulations, it is clear that a large volume of illegal mahogany continued to be exported from many of these countries (Blundell \& Rodan, 2003). Ironically, CITES only served to give a veneer of legality to what was otherwise illegal wood.

\section{Stricter domestic legislation}

In addition to CITES, countries also attempted to control the exploitation of mahogany through legislation, but a lack of political will and poor enforcement have lead to weak implementation of these domestic measures (Blundell \& Gullison, 2003). In 1996 Bolivia passed a new Forestry Law (\#1700, Art. 27 \& 37) that requires management plans and a $\$ 1$ ha $^{-1}$ year $^{-1}$ concession fee. The Forest Superintendent also fixed a quota on mahogany exports, and the Bolivian CITES Scientific Authority has been issuing non-detriment findings for each shipment of mahogany. Despite this, a Presidential decree (Decreto Supremo No. 25561) allowed mahogany from indigenous reserves to be exported, effectively forcing the 1999 quota to be doubled from c. 5,200 $\mathrm{m}^{3}$ (as set by the Forest Superintendent) to $c .11,000 \mathrm{~m}^{3}$.

Perú also enacted a new Forestry Law (No. 27308 in July 2000) which, among other regulations, requires management plans for all concessions (previously concessions $<1,000$ ha had not required plans). Implementation has been extremely difficult. In June 2002, upset with the new regulations, loggers burned the Puerto Maldonado offices of both INRENA (the Forestry Department) and the NGO ProNaturaleza. A main actor behind these protests has since become Governor of Madre De Dios, and thus has responsibility for the local management of mahogany and other timber species.

Brazil has recently taken the toughest stand against widespread illegal logging of mahogany, suspending all commercial trade in 2001. Prior to this, the National Forestry Law No. 4771 required reduced-impact logging and management plans based on pre-harvest inventories (TRAFFIC, 2001). Since 1996 no new permits to log mahogany have been awarded, which effectively created a cartel of producers (Presidential Decree 1963/1996, renewed by Decree 2687/1998, Decree 2559/2000, and Decree 4335/2002). Export quotas were steadily decreased, falling from $150,000 \mathrm{~m}^{3}$ in 1990 to $50,000 \mathrm{~m}^{3}$ in 2000 (Government of Brazil, 2001). 
In 1996 IBAMA (the Brazilian federal agency responsible for forestry) examined 700 forestry management plans and suspended $75 \%$ for non-compliance with Brazilian laws and regulations, widespread technical irregularities, and fraud (TRAFFIC, 2001). Of 95 logging operations for mahogany in Pará, only 21 had management plans. Nevertheless, mahogany was exported; 11 companies without management plans exported to the UK (Hering \& Tanner, 1998). In a subsequent, 1999 review, IBAMA suspended 29 of the 31 remaining operations. Despite this, legal challenges raised the export quota by c. $20 \%$ : by $11,000 \mathrm{~m}^{3}$ in 1998 (TRAFFIC, 1999) and by $12,962 \mathrm{~m}^{3}$ in 1999 (TRAFFIC, 2001).

By 2001 IBAMA determined that permits to transport mahogany (ATPFs) from the remaining management areas 'were being used by the logging industry to legalize mahogany harvested hundreds of kilometers from the nearest authorized management area' (IMAZON, 2002). Greenpeace (2001) documented c. 8,000 $\mathrm{m}^{3}$ of illegal mahogany from Kayapó indigenous lands. Reacting to the report, IBAMA and the Federal Police launched Operation Mahogany, confiscating $>28,000 \mathrm{~m}^{3}$ of mahogany logs extracted from within the Terra do Meio between the Xingu and Iriri Rivers in central Pará. Consequently IBAMA suspended all management plans for mahogany in Brazilian Amazonia until operations could be certified (Instrução Normativa No 22/2001). Currently, only 300,000 ha are managed for mahogany and are certified by the Forest Stewardship Council, all in Central America (FSC, 2003).

To circumvent the ban several exporters won court cases in December 2001, forcing IBAMA to allow exports (ITTO, 2002). Greenpeace tried to prevent $811 \mathrm{~m}^{3}$ from entering the UK, but the British court ruled that there was insufficient evidence to determine if the mahogany was illegal. This was despite the fact that many of the CITES documents accompanying the disputed shipments had serious irregularities, including the absence of stamps and signatures, and IBAMA had written on the permits 'subject to precarious judicial precedent'. IBAMA has appealed against the ruling and, should they win, the shipments could be declared illegal. However, it will be too late to recover the mahogany that has already been sold. Elsewhere in Europe shipments are still being held. The CITES Secretariat considers the export permits to be invalid because they were issued contrary to the provisions of the Convention. Based on this, the European Commission advised Member States not to accept imports (DG ENV.E.3/CB/CO/kk D(2002)630163).

In the US, more than 47 shipments $\left(>8,400 \mathrm{~m}^{3}\right)$ were stopped until IBAMA could confirm their legality. IBAMA confirmed that 37 shipments were legally obtained and the US released all but 10 full and 2 partial shipment of c. 2,000 $\mathrm{m}^{3}$ (APHIS, 2003). In July 2002 seven American importers sued the US government for continuing to hold these shipments, but in April 2003 a US court ruled that the US CITES Authorities had the right to refuse entry to these disputed shipments. (There is no US law preventing the importation of illegally harvested timber, only that imports must comply with trade and CITES regulations.) Despite the trade ban, IBAMA seized another raft of 7,000 mahogany logs (c. $18,000 \mathrm{~m}^{3}$, valued at $\$ 29$ million) along the Xingu River in June 2002. The mahogany had been illegally cut from indigenous reserves.

\section{Implementation of Appendix II}

Given the difficulties controlling mahogany's harvest and trade, implementation of Appendix II is likely to be problematic (Rodan \& Blundell, 2003). Under CITES regulations, protocols must be developed by each country's CITES Management Authority to verify legality, and by their Scientific Authority to confirm that harvests were non-detrimental to the survival of mahogany in its role in the ecosystem throughout its range. This will require a system that tracks logs from the stump to export in order to segregate legal mahogany from the large volumes that are being illegally harvested (i.e. maintain a chain-of-custody). Furthermore, it will require enforcement systems to ensure that loggers comply with laws and regulations already in place that require sustainable management (TRAFFIC, 1999, 2001). Implementation can be facilitated if the procurement policies of international buyers require such a chain-of-custody.

Developing such systems will be a challenge, especially given that they must be in place before Appendix II regulations enter force on 15 November 2003. In Pará, IBAMA has only 77 inspectors responsible for 1,200,000 $\mathrm{km}^{2}$, an area almost three times the size of California. Given such limited capacity, it is difficult to see how Appendix II will be implemented on time.

Although each country reserves the sovereign right to develop a National Plan to implement CITES regulations, other countries can review these plans. Should countries fail to establish meaningful scientific standards and ensure that loggers comply, the international community may act through the CITES Significant Trade Review Process. In such cases, the CITES Plants Committee can insist on export quotas, trade bans, and the 'application of adaptive management procedures to ensure that further decisions about the harvesting and management of the species concerned will be based on the monitoring of the impact of previous harvesting and other factors' (CITES Resolution 12.8).

Certification systems, such as the Forest Stewardship Council, may be useful in verifying that mahogany 
shipments are both legal and non-detrimental. In British Columbia, Canada, certified forestry operations receive regulatory relief; i.e. if their operation is chosen for inspection, the Forest Practices Board (2003) conducts a reduced audit compared to non-certified operations.

Although implementation is a challenge, CITES may prove the only instrument available to halt the unsustainable exploitation of mahogany. If it does not the commercial mahogany trade may suffer the fate of Cuban mahogany S. mahagoni L. and Mexican mahogany S. humilis Zuccarini. These mahoganies once dominated international commerce, but are no longer in trade, having been driven to commercial extinction by overexploitation and habitat loss (Robbins, 2000).

The parties to CITES recognized the threat of commercial extinction and chose to regulate international trade by listing mahogany on Appendix II. This decision represents a major challenge. As the first commonly traded timber species to be listed on Appendix II, there is no precedent for implementation. The first challenge will be to reform the mahogany industry, at both the producing and consumer ends, to eliminate the illegal logging. Strong political will and international cooperation are essential to meeting this challenge. If such cooperation is not achieved, Latin American risks losing one of its most valuable resources.

\section{Acknowledgements}

I thank Jimmy Grogan, Ted Gullison, Emily Harwell, Shirlee Tan and Bruce Rodan for their help with this manuscript. The views expressed in this paper do not necessarily represent those of the US government.

\section{References}

APHIS (U.S. Department of Agriculture's Animal and Plant Health Inspection Service) (2003) USDA Continues to Protect Big-leaf Mahogany. Press release 21 March 2003. Washington, DC, USA [http://www.aphis.usda.gov/lpa/news/2003/ 03/bigleaf6_ppq.html, accessed 16 November 2003].

Barreto, P., Amaral, P., Vidal, E. \& Uhl, C. (1998) Costs and benefits of forest management for timber production in Eastern Amazonia. Forest Ecology and Management, 108, 9-26.

Blundell, A.G. \& Gullison, R.E. (2003) Poor regulatory capacity limits the ability of science to influence the management of mahogany. Forest Economics and Policy, 5, 395 -405.

Blundell, A.G. \& Rodan, B.D. (2003) Mahogany and CITES moving beyond the veneer of legality. Oryx, 37, 85-90.

Browder, J. O. (1987) Brazil's export promotion policy (1980 - 1984): impacts on the Amazon's wood sector. The Journal of Developing Areas, 21, 285-304.

CCT (Centro Cientifico Tropical) (2000) Diagnostico de la Caoba en Mesoamerica: Vision General. Unpublished Report. Centro Cientifico Tropical, San Jose, Costa Rica.

CI (Conservation International) (2001) Protected Areas and Forest Cover. CITES Mahogany Working Group, Santa Cruz, Bolivia, 3-5 October 2001.
CITES (2002) Consideration of Proposals for Amendment of Appendices I and II. Prop. 12.50, CITES Conference of Parties, Santiago, Chile, November, 2002 [http:/ / cites.org/eng/cop/ 12/prop/E12-P50.pdf, accessed 16 November 2003].

Cochrane, M.A. (2001) In the line of fires: understanding the impacts of tropical forest fires. Environment, 43, 28-38.

Forest Practices Board (2003) Compliance Audit Reference Manual. Forest Practices Board, Victoria, Canada

[http://www.fpb.gov.bc.ca/a_reference.htm [accessed 16 November 2003].

FSC (Forest Stewardship Council) (2003) Forests Certified by FSC-Accredited Certification Bodies. Http://www.fscoax.org/ principal.htm [accessed 16 November 2003].

FUNATURA (Fundação Pró-Natureza) (1993) Projeto Mogno. Sumário: Occorência e Distribuição de Mogno na Amazônia. Unpublished Report, Brazil.

Gerson, H. (2000). An Investigation of the Tropical Timber Trade in Canada with Emphasis on the Compliance, Reporting and Effectiveness of Legislation and Regulatory Procedures for CITES-Listed Timber Species. Unpublished report, Canada Customs and Revenue Agency, London, Canada.

Gillies, A.C.M., Navarro, C., Lowe, A.J., Newton, A.C., Hernandez, M., Wilson, J. \& Cornelius, J.P. (1999) Genetic diversity in Mesoamerican populations of mahogany, assessed using RAPDs. Heredity, 83, 722-732.

Government of Belize (2001) National Report. CITES Mahogany Working Group, MWG1 Doc. 8, Santa Cruz, Bolivia, 3-5 October 2001.

Government of Bolivia (2001) National Report. CITES Mahogany Working Group, MWG1 Doc. 8.8, Santa Cruz, Bolivia, 3-5 October 2001.

Government of Brazil (2001) Assessment of the Current Mahogany Market and Trade Situation. CITES Mahogany Working Group, MWG1 Doc. 8.12, Santa Cruz, Bolivia, 3-5 October 2001.

Government of Colombia (2001) National Report. CITES Mahogany Working Group, MWG1 Doc. 8.15, Santa Cruz, Bolivia, 3-5 October 2001.

Government of Costa Rica (2001) National Report. CITES Mahogany Working Group, MWG1 Doc. 8.6, Santa Cruz, Bolivia, 3-5 October 2001.

Government of Peru (2001) National Report. CITES Mahogany Working Group, MWG1 Doc. 8.4, Santa Cruz, Bolivia, 3-5 October 2001.

Greenpeace (2001) Partners In Mahogany Crime. Greenpeace International, Amsterdam, The Netherlands.

[http://www.greenpeaceusa.org/forests/mahogany.pdf, accessed 16 November 2003].

Grogan, J.E. (2001) Big-leaf mahogany in Southeast Pará, Brazil: a life history study with management guidelines for sustained production from natural forests. PhD thesis, Yale University, USA.

Grogan, J., Barreto, P. \& Veríssimo, A. (2002) Mogno na Amazônia Brasileira: Ecologia e Perspectivas de Manejo. Unpublished Report, Imazon, Belém, Pará, Brazil [http://www.imazon.org.br/english/index.htm, accessed 16 November 2003].

Grogan, J., Galvão, J., Simões, L. \& Veríssimo, A. (2003) Regeneration of big-leaf mahogany in closed and logged forests of Southeastern Pará, Brazil. In Big-Leaf Mahogany: Genetics, Ecology, and Management (eds A. Lugo, J.C. Figueroa Colón \& M. Alayón) pp. 193-208. Springer-Verlag, New York, USA.

Gullison, R.E. (1995) Conservation of tropical forests through the sustainable production of forest products: the case of mahogany 
(Swietenia macrophylla King) in the Chimanes Forest, Beni, Bolivia. PhD thesis, Princeton University, USA.

Gullison, R.E., Panfil, S., Strouse, J.J. \& Hubbell, S.P. (1996) Ecology and management of mahogany (Swietenia macrophylla King) in the Chimanes Forest, Beni, Bolivia. Botanical Journal of The Linnean Society, 122, 9-34.

Gullison, R.E., Rice, R.E. \& Blundell, A.G. (2000) 'Marketing' species conservation. Nature, 404, 923-924.

Hering, R. \& Tanner, S. (1998) Plunder For Profit: The UK and Brazilian Mahogany Trade. Friends of the Earth Publication, London, UK [http:/ / www.foe.co.uk/resource/reports / plunder_for_profit.pdf, accessed 16 November 2003].

Howard, A.F., Rice, R.E. \& Gullison, R.E. (1996) Simulated economic returns and environmental impacts from four silvicultural prescriptions applied in the neotropics: a case study of the Chimanes Forest, Bolivia. Forest Ecology and Management, 89, 43-57.

IMAZON (2002) Imazon Supports Increased Control over International Trade of Mahogany: The Species' Proposed Listing on Cites Appendix II. Unpublished Report, Imazon, Belém, Pará, Brazil.

ITTO (International Tropical Timber Organization) (2002) Tropical Timber Market Report. Unpublished Report. International Tropical Timber Organization, Yokohama, Japan.

ITTO (International Tropical Timber Organization) (2003) Tropical Timber Market Report. Unpublished Report. International Tropical Timber Organization, Yokohama, Japan.

Lamb, F.B. (1966) Mahogany of Tropical America: Its Ecology and Management. University of Michigan Press, Ann Arbor, USA.

Loveless, M.D. \& Gullison, R.E. (1996) Genetic variation, population differentiation, and mating systems in natural populations of mahogany Swietenia macrophylla in the Beni, Bolivia. Presentation to the international conference on big-leaf mahogany, San Juan, P.R., 22-24 October 1996. USDA Forest Service, International Institute of Tropical Forestry, Río Piedras, Puerto Rico.

Nepstad, D,C., Verissimo, A., Alencar, A., Nobre, C., Lima, E., Lefebvre, P., Schlesinger, P., Potter, C., Moutinho, P., Mendoza, E., Cochrane, M. \& Brooks, V. (1999) Large-scale impoverishment of Amazonian forests by logging and fire. Nature, 398, 505-508.

Robbins, C. (2000) Mahogany Matters: The US Market for Big-Leafed Mahogany and its Implications for the Conservation of the Species. Unpublished Report. TRAFFIC North America, Washington, DC, USA [http://www.worldwildlife.org/ forests/attachments/mahogany.pdf, accessed 16 November 2003].

Rodan, B.D. \& Blundell, A.G. (2003) Can sustainable mahogany stem from CITES science? Bioscience, 53, 619.
Snook, L.K. (1996) Catastrophic disturbance, logging and the ecology of mahogany (Swietenia macrophylla King): grounds for listing a major tropical timber species on CITES. Botanical Journal of the Linnean Society, 122, 35-46.

SPDA (Sociedad Peruana de Derecho Ambiental) (2002) Illegal Mahogany Logging in the Districts of Iñapari and Iberia, Madre De Dios, Peru: The Role of the Newman Lumber Company. Http://www.aida2.org/english/projects/prjlogs.php. [accessed 16 November 2003].

TRAFFIC (1999) Steps Towards Improved Regulation of Trade in Big-leaf Mahogany. Http:/ / www.traffic.org/bulletin/ archive/january99/improved_regulation_mahogany.html [accessed 16 November 2003].

TRAFFIC (2001) Legislation and Controls for Harvest and Trade of Big-leafed Mahogany in Bolivia, Brazil, and Peru. Http:/ / www.traffic.org/mahogany/legis.html [accessed 16 November 2003].

UNEP-WCMC (UNEP-World Conservation Monitoring Centre) (1999) Contribution to an Evaluation of Tree Species Using the New Cites Listing Criteria. Http:/ / www.unep-wcmc.org/species/tree_study/ [accessed 26 May 2003].

Veríssimo, A., Barreto, P., Tarifa, R. \& Uhl, C. (1995) Extraction of a high-value natural resource in Amazonia: the case of mahogany. Forest Ecology and Management, 72, 39-60.

Veríssimo, A. \& Grogan, J. (1998) Meeting of the Working Group on Mahogany: Synthesis of the Situation of Mahogany at the International Level. Inf. Rep. Nr. 02-98-English. MMA-FAO-PNUD. Brasilia, Brazil.

Weaver, P.L. \& Sabido, O.A. (1997) Mahogany in Belize: an historical perspective. Presentation to an international conference on big-leaf mahogany, San Juan, P.R., 22-24 October 1996. USDA Forest Service, International Institute of Tropical Forestry, Río Piedras, Puerto Rico.

Zimmerman, B.L., Peres, C.A., Malcolm, J.R. \& Turner, T. (2001) Conservation and development alliances with the Kayapó of Southeastern Amazonia, a tropical forest indigenous people. Environmental Conservation, 28, 10-22.

\section{Biographical sketches}

Art Blundell is interested in developing incentives to foster the better management of forests. In particular he has been working as an AAAS Science-Policy Fellow at the US Agency for International Development and the Environment Protection Agency on mahogany and CITES. More recently he has been working with the UN Security Council to reform the forest industry in Liberia and to eliminate conflict timber. 